\title{
The Armenians in Brazil and the Genocide in Diaspora
}

\section{Heitor de Andrade Carvalho Loureiro}

The arrival of a great wave of Armenian immigrants to Brazil, especially during the 1920ies, did not end the series of persecutions that they were suffering since 1915 , with the start of the Genocide perpetrated by the Ottoman government. Even far from Anatolia, their historical land, some Armenians were closely monitored by the Brazilian security services, as considered dangerous elements for the society.

The repression of Political and Social Order Police of the State of São Paulo (DEOPS/SP - 1924-1983), created in a context of political repression and ideological formation against those who were considered harmful to the status quo, mainly the anarchists and foreigners ${ }^{1}-$ applies to a good fraction of the Armenian community, which according to the authorities, "all belong to Soviet Armenia and are communists, supporters and admirers of Stalin,"2 a clear attempt to demonize all political enemies. We must ask: if the spread of the "communist belief" among Brazilians already caused fear to authorities, what can we infer when we reflect on individuals linked to a country that at this point was a member of the Soviet Union?

According to Tucci Carneiro, Political Police takes the lead in repression to "domesticate the masses," homogenizing different tendencies and

\footnotetext{
${ }^{1}$ Pedroso, Regina (2005). Estado Autoritário e Ideologia Policial. (São Paulo: Laboratório de Estudos sobre Intolerância/Humanitas/FAPESP), pp. 112-114.

${ }^{2}$ Criminal Record no 98.438 - Vartavar Tchungurian. Fundo DEOPS/SP, Public Archives of the State of São Paulo-Brazil (APESP).
} 
disarming beliefs and values considered to be "potentially dangerous" 3 . Regina Pedroso, declares that "Communism is the disruptive element of society, against all morality and good manners, which is expressed by the destruction and violence trumpeted against Getulio Vargas' state ${ }^{4}$.

But what it looked like the communism of Armenians during the period from 1935 to 1969 ? And in which way repression watched and acted against the political action of the Armenian immigrants in Brazil during these years? These are the questions this study intends to answer.

Those Armenians labeled as communists fit perfectly into the stereotyped profile that repression had created to frame undesirable elements, "revolutionaries, protesters, trade unionists, foreigners, workers, anarchists and subversives ${ }^{5}$."

However, to extend naturally to all Armenians the Communist label, as did the Brazilian Political Police, is a big mistake and must be avoided by all means. Therefore, to not reproduce the official discourse of repression, we need to understand the Armenian immigration in Brazil, as well as the political nuances that divide in the community since the first immigrants arrived to the country.

The Armenian Genocide - from 1915 to 1923 - was largely responsible for the significant Armenian communities dispersed throughout the

\footnotetext{
${ }^{3}$ Carneiro, Maria Luiza Tucci (1999). "O Estado Novo, o Dops e a ideologia da segurança nacional”. In: PANDOLFI, Dulce (org). Repensando o Estado Novo. (Rio de Janeiro: FGV), pp. 335-336.

${ }^{4}$ Pedroso. op. cit. p. 129.

${ }^{5}$ Ibid., p. 114.
} 
world. First genocide of the Twentieth century and the longest in history ${ }^{6}$, this phenomenon was an action systematically organized by the Ottoman government, ruled by Committee of Union and Progress, known as the "Young Turks" party, with the objective of exterminating the Armenian population of the six provinces of Anatolia. This process served a purpose: to keep alive the Ottoman Empire that brought serious cracks in its structure after years of economic and political crisis, which cost to 'Sublime Porte' the loss of the Balkans, a defeat the Ottoman government would never overcome. To annihilate the Armenians in Anatolia was an attempt to prevent them from entering into a revolutionary fever that could culminate in the independence of this region, which would be the end of the already weakened Ottoman Empire. About 1.5 million Armenians were killed and 350,000 emigrated before or after the massacres ${ }^{7}$. The map of the Armenian Diaspora leaves no doubt about the size of destruction: it is estimated that, while about 3.1 million Armenians lived in Soviet Armenia, other 3.5 million were spread around the world ${ }^{8}$.

Unlike other ethnic groups, there was not a specific public policy to stimulate Armenian immigration to Brazil, as it happened for example in France, where Armenians served as a labour force to fill vacancies created by the French killed during the First World War ${ }^{9}$. This fact explains somehow the small number of Armenians who immigrated to Brazil when compared with workers from other countries, or if we look at the numbers of Armenian immigrants in

\footnotetext{
${ }^{6}$ Thesis supported by Campolina Martins (1998, p. 154, note 16). Since there isn't an acknowledgment of the Genocide by the Republic of Turkey - the legal successor of Ottoman Turkish legacy - we can't talk about a legal outcome about the issue, which remains open up to the moment.

${ }^{7}$ Sapsezian, Aharon. (1988). História da Armênia. (Rio de Janeiro: Paz e Terra), p. 160.

${ }^{8}$ Ibid., pp. 161-162.

${ }^{9}$ Ibid., p. 164.
} 
countries that encouraged their arrival and contribution. It is estimated that around 40,000 Armenians and descendants live today in Brazil, the majority in the state of São Paulo ${ }^{10}$.

The arrival of the largest contingent of Armenian immigrants is concentrated between 1924-1926, reaching the number of 5,000 Armenians in the country in 1935, attracted mainly by the experience of the Arabs in Syria and Lebanon - where the Armenians found refuge after Genocide. Those immigrants used to tell in letters to family about their success and victory in Brazil $^{11}$.

The origin of most Brazilian Armenians is the region of Cilicia - or Lesser Armenia - south coastal region of Asia Minor, on the shores of the Mediterranean. The city of Marash is the birthplace of the majority ${ }^{12}$ - these old relationships and family ties would contribute to their cooperation and social life in the new country. The first to come organized themselves in groups and started small businesses, mainly linked to peddling, shoe manufacturing and trading.

More than just a craft, and an income source, those Armenian shoe factories served as the first spaces of social relationship among the new arrivals. It was for 'doing business' that Armenians gathered and supported each other, in order to encourage new artisans who had just arrived from the east and lacked the means to start an activity. Those who were already adapted

\footnotetext{
${ }^{10}$ Armenia 2020: Diaspora-Homeland Issue Paper (2003). (Yerevan, Armenia: Arak-29, Foundation), pp. 3-4.

${ }^{11}$ Kechichian, Hagop (2000). Os Sobreviventes do Genocídio: imigração e integração armênia no Brasil, um estudo introdutório. (São Paulo: PhD Thesis, FFCHL/USP), pp. 31-51.

12 Ibid., p. 24.
} 
and financially stable provided support and assisted the newcomers with capital and raw materials so that they could start their life in the country ${ }^{13}$.

From then on, the social and political life of the community took shape. The first societies and organizations were founded in order to build the two pillars of the existence of Armenians in Diaspora: The Church and the parties $^{14}$.

Political organizations are first moment institutions within the Armenian Brazilian community. In Brazil, as well as throughout Armenian Diaspora, we point out three major parties: Armenian Revolutionary Federation (ARF), Social Democratic Party and Democratic Liberal Organization.

Regarding the general boiling partisan political character of the Armenian community, allied to the unstable Brazilian political situation from 1930ies-to the 60ies, it would not be surprising to observe the movement of immigrants already settled, either in the Armenian community associations or else in Brazilian organizations. In this sense, we try to understand why Political Police authorities filed Armenians on the charge of communism, a dangerous ideology for the nation at those days.

For the Armenians, supporting the Soviet Union was not necessarily a gesture of support for communism. Even the Liberal Democratic Organization, a center-right party, kept a dialogue and, somehow, was enthusiastic about Soviet Armenia, since it was the inclusion of the country in the Soviet Union which guaranteed the maintenance of a homeland, away from the constant

\footnotetext{
${ }^{13}$ Ibid., pp. 46-49.

${ }^{14}$ Sapsezian, Aharon. (1988). Op. cit., p. 167.
} 
Turkish threat. There was not a specific communist party within the Armenian associations, just individuals sympathetic to Communist ideals who could have a militant activity within the Brazilian community and spread this ideas among their fellow Armenians.

In an interview to a newspaper in the city of Londrina, in 1983, José Balikian said "our country [Armenia] has always been very poor. There were only elementary schools. Today, as socialists, they have everything ${ }^{15}$." The declaration of Balikian may involve enthusiasm for communism, as well as the maintenance of Armenian territory with well defined boundaries and the improving living conditions of the population of Soviet Armenia, compared to the Ottoman period. In this sense, Armenian communism and nationalism are inseparable.

The testimony of actor and politician Stepan Nercessian about his father, Garabed, follows in the same direction. A notorious communist, Garabed discourages his son Stepan to fuel hatred or revenge against Turks, because, in his words, although Armenians, they were socialists, communists, and the purpose of Armenian communists in this world was not revenge, but to fight hard so that those atrocities would never again happen to mankind ${ }^{16}$. In his statement, although not mentioning Soviet Armenia, Garabed reveals the role of Armenians for all mankind, according to the internationalist tradition of communism, without forgetting their ancestral origin.

\footnotetext{
${ }^{15}$ Folha de Londrina, (August 08th, 1983).

${ }^{16}$ Testimony of Stepan Nercessian. Documentary "Chegados: Armênia”. Canal Futura, 2007.
} 
But Levon Yacoubian ${ }^{17}$ is one of the most prominent faces of Communism within the Armenian community of Brazil. In a newspaper article, Yacoubian glorifies Stalin, calling the leader of the Soviet Union "the best of the unconditional friends of our Homeland (Armenia)" and "immortal heritage of mankind ${ }^{18}$." Here, we feel the enthusiasm of Yacoubian with the Soviet leader, which, according to him is a crucial figure for the survival of Armenia in the world. Yacoubian goes further, saying:

"Only the socialist power of the Armenian workers, peasants and intellectuals managed to finally defeat, in Armenia, the regressive powers of the tashnag government of Vratsian. It was only the socialism that put the government power in the hands of the Armenian people, once enslaved and plundered by a handful of tashnag lackeys". ${ }^{19}$

Besides being an enthusiast of Socialism as an ideal system of government for Armenia, the political stance advocated by the author attacks directly the position of ARF, largest political party in the Armenian Diaspora. Thus, we can see that the brawl of the Communist Armenians with ARF was raised from the direction that Republic of Armenia had taken, and, probably, these decisions in the Motherland stirred up the mood in the Brazilian community, up to the point of Yacoubian becoming so aggressive in his article. The author concludes his text: "ARARAT, in this seventieth anniversary of Stalin, reaffirms its unyielding line of conduct: to unmask the tashnags, fight against imperialism and war in defense of Peace."

\footnotetext{
${ }^{17}$ Criminal Record nº. 73.631- Levon Yacubian. Fundo DEOPS/SP - APESP.

${ }_{18}^{18}$ Ararat - A voz do povo armênio. Ano IV, no. 39-40; December 1949 to January 1950, p. 1.

${ }^{19}$ Idem. ARF and Tashnag are two different designations for same political party.
} 
Therefore, we realize that the communism of the Armenians in São Paulo is far from having only one aspect. Far beyond an ideology, communism served as an important tool of criticism and opposition within the Armenian community.

This mixture of sympathy towards communist ideals and the need to be guided in this way to oppose the ARF, as well as to support Soviet Armenia shows how the Armenian Genocide caused damages far beyond the 1.5 million deaths.

The political groups of the Armenian Diaspora in Brazil disputed over a memory of Armenia. And such confrontations made through institutions and community newspapers attracted the attention of law enforcement authorities of the State, which felt in these movements a subversive and dangerous feature for the national sovereignty. Of course, there were no Armenians killed in Brazil simply for being Armenians. But the fact that Armenians have been closely watched and imprisoned for keeping in touch and attentive to what happened in their own community and the Motherland shows that in the Diaspora - a direct result of Genocide - they suffered the consequences of the deportations and persecutions occurred in the Ottoman Empire.

Finally, this review would like to contribute to the idea that studying a Diaspora is definitely to study Genocide, because the first is the direct consequence of the second. The better we understand the singularities of the widespread Armenian communities around the world, the more we will come to know the depth of the first Genocide of the Twentieth century. 